\title{
Social Co-Governance for Food Safety Risks
}

\author{
Linhai Wu ${ }^{1, *}$, Pingping Liu ${ }^{1}$, Yuxin Lv ${ }^{1,2}$, Xiujuan Chen ${ }^{1}$ and Fu-Sheng Tsai ${ }^{3,4,5, *}$ \\ 1 Institute for Food Safety Risk Management, School of Business, Jiangnan University, Wuxi 214031, China; \\ lppjndx@163.com (P.L.); lvyuxin@zju.edu.cn (Y.L.); xjchen@jiangnan.edu.cn (X.C.) \\ 2 Ocean Research Center of Zhoushan, Zhejiang University, Zhoushan 3160217, China \\ 3 Department of Business Administration, Cheng Shiu University, Kaohsiung 83347, Taiwan \\ 4 Center for Environmental Toxin and Emerging-Contaminant Research, Cheng Shiu University, \\ Kaohsiung 83347, Taiwan \\ 5 Super Micro Mass Research \& Technology Center, Cheng Shiu University, Kaohsiung 83347, Taiwan \\ * Correspondence: wlh6799@jiangnan.edu.cn (L.W.); tsaifs@gcloud.csu.edu.tw (F.-S.T.); \\ Tel.: +86-0510-85325277 (L.W.)
}

Received: 9 September 2018; Accepted: 13 November 2018; Published: 17 November 2018

\begin{abstract}
We review relevant literature to propose the connotation and operation logic of food safety co-governance, systematically constitute by roles, functions, as well as the boundaries of public government, enterprise, and social forces. The major thesis is that social co-governance is a kind of societal-wide innovation (i.e., social innovation) that integrates diverse resources and efforts from multiple stakeholders for better and sustainable development of an economy's food institution and system. We then put forward a prospect of the future research on food safety risk co-governance. Theoretical, practical, and policy implications are discussed.
\end{abstract}

Keywords: food safety risk; social co-governance; literature review; research prospects; social innovation; sustainability

\section{Background}

Food safety risks around the world have proposed challenges faced by all countries [1-5]. Each year approximately 18 million people die from consumption of unhygienic food and water [6]. In terms of economic theory, the root cause of food safety problems is information asymmetry between food consumers and manufacturers. Market failure that is caused by information asymmetry needs to be addressed by government administrative intervention [7]. Therefore, food safety regulations in most developed countries focus on regulating food production processes or safety levels by mandatory standards. However, the bovine spongiform encephalopathy crisis in 1996, which originated in the United Kingdom and caused global panic, and other major food safety incidents that followed, have shaken and seriously dampened public confidence in the government's ability to manage food safety risks $[8,9]$. Under the circumstances, the governments urgently needed to find more effective approaches to food safety risk governance in response to public expectations and media pressure [10]. Since, the governments of developed countries began to reform the structure of food safety regulations [11-13]

Among the newly proposed thinking, co-governance has emerged as a more transparent and effective way by encouraging social participation for the collective pursuit of food safety [14-16]. Extensive social governance practices in developed countries have demonstrated that outsourcing some public governance functions can solve tight government budgets and limited governance resources $[17,18]$. With the rapid development of food production technology and the increasingly international supply chain, non-government actors, such as companies and industry associations, have unique advantages in food production technology and management [19]. They can supplement 
government efforts and play an important role in preventing food safety risks [20]. When compared with traditional governance mechanisms, co-governance can guarantee food safety with lower costs and more efficient resource allocation, and thus has become the basic form of food safety risk governance worldwide [21].

In view of the more complex and premature regulatory systems, it is clear that a regulatory approach that relies solely on the government is unlikely to be effective in food safety risk governance. Knowing this, many of the new economies in the world started to take the social governance way alone with their other open dimensions in national development. For example, at the National Food Safety Awareness Week held in June 2013, Yang Wang, Vice-Premier of the State Council of China, explicated the concept of food safety risk co-governance for the first time. The core elements of such idea are "corporate self-governance, government regulation, social cooperation, public participation, and legal protection". Additionally, in the Food Safety Law of China, co-governance has become the basic principle for food safety risk governance in China.

Emphasized heavily in practices though, co-governance is academically a new concept, of which a systematic review for the literature is wanting. The investigation of major theoretical issues regarding food safety risk co-governance, such as basic connotation, internal logic, and scope definition, is still in its infancy as to academic community, the government, and civil society. In view of this, the purpose of this paper is to review the evolution of theoretical issues regarding food safety risk co-governance from the perspectives of connotation, operational logic, and scope of each actor based on recent studies in other countries, in order to provide reference for future studies.

\section{Social Co-Governance for Food Safety Risk}

In the late 20th century, the high welfare policies of developed countries resulted in overstaffed and inefficient government agencies [22]. The regulatory capacity of the government lagged behind social development, especially in the management of environmental protection, market monopolies, and food safety issues [22]. At the same time, the overall rise of social organizations and citizen groups greatly promoted the development of social governance [23]. The government had to coordinate and cooperate with social actors in many aspects [23]. By the end of the 20th century, the theory of social governance emphasizing construction of a collaborative network that enables multilateral interaction between diverse, decentralized actors began to blossom [24]. An inclusive and flexible concept of co-governance was formed. In general, the main actors of social governance include the government, non-governmental organizations (social organizations, communities, and media), market players (manufacturers), and individuals [24]. The goals of social governance are to control strategic direction, coordinate social economy and cultural environment, coordinate conflicts of interest between different groups, utilize resources efficiently, prevent externalities, serve customers, and ultimately maximize social benefits [25]. The forms of social governance include rule by law, rule by virtue, self-governance, and co-governance [26]. Noticeably, actors that are involved in governance are equal partners, which is different from top-down, vertical, one-way government governance activities [27]. As an important form of governance, co-governance is an extension and concretization of the social governance theory. At present, co-governance is mainly defined from the perspectives of mechanism and actors [28].

\subsection{Mechanism}

As to the concept of co-governance, Ayres and Braithwaite, and Cary and David suggest that co-governance can be understood as social self-governance under government regulation. It is the extension and development of a unitary government governance mechanism [29], and social self-governance based on government regulation [30]. It combines government regulation and social self-governance [31]. Fairman and Yapp indicate that co-governance is social self-governance under the regulation of external actors, such as the government [32]. Despite their different wordings, these statements convey the same meaning, that is, co-governance is a middle way that combines traditional government regulation and social self-governance without government regulation. On this 
basis, Sinclair argues that manifestations of co-governance are bound to vary greatly as government regulation and social self-governance can be combined in diverse ways [33].

\subsection{Actors}

In the early 1990s, the Dutch government believed that the establishment of a clear coordination and collaboration relationship between the government and social actors, including citizens and social organizations, within the legal framework was very important for improving the quality of legislation. To this end, the subsidiary principle was clearly proposed in relevant documents. This is an early form of co-governance in government documents. In 2000, the British government incorporated co-governance in the Communications Act 2003, and viewed it as a process of ensuring that an effective and acceptable plan is developed by the active and interactive participation of all actors. This actually considers co-governance as a form of cooperation between government agencies and companies in social governance [34]. In this case, governance responsibilities are shared by the government and companies as agreed in the cooperation [35]. Furthermore, Eijlander argues from a legal point of view that co-governance is a hybrid approach to solve specific problems through coordination and cooperation between government and non-government actors, which results in agreements, conventions, and even laws [36]. Elodie and Julie suggest that co-governance is the process by which government and non-governmental organizations, including the general public, as well as other stakeholders, jointly formulate or participate in the formulation of laws and governance agreements or rules [37].

In view of the importance of preventing food safety risks, researchers have extended the concept of co-governance to food safety risk governance. Fearne and Martinez defines food safety risk co-governance as the process by which the government and companies cooperate to construct an effective food safety system to ensure better food safety in production and protect consumers from risks, such as foodborne diseases, under the premise that all stakeholders in the food supply chain (from production to consumption) can benefit from improved governance efficiency [38]. Marian suggests that food safety risk co-governance is the process by which the government and social organizations coordinate and cooperate in setting food safety standards, process implementation, enforcement, and monitoring in order to provide higher quality and safer food at a lower governance cost [21]. Standards setting refers to development of references of quality level when defining acceptable food quality and safety. Process implementation simply refers to putting those stands into practices. Enforcement refers to ensuring the correct implementation through law and regulation. Monitoring refers to a constant review of the situation in accordance to the implementation of food safety and quality standards.

Based on the theoretical research results and experiences of developed countries, it is proposed in this paper that food safety risk co-governance is the process by which all participating actors cooperate and work together based on their respective functions to regulate food safety at a lower cost by the combined and synergetic use of multiple instruments, such as government regulation, market incentives, technical regulation, social supervision, and information dissemination, under the framework of laws and regulations and under the premise of balancing the interests and responsibilities of the diverse actors, in order to ensure higher level of food safety and achieve maximum social welfare. In the nature of the proposed model of social co-governance, it ideally has an assumption of 'balance' between multiple parties. Without balance (i.e., a situation of dis-equilibrium of the power relations among government, company, and society), the "co-" governance could not be possible. Thus, it is difficulty to offer the negative outcome of the social co-governance model per se (emphasis added).

Note that the concept of co-governance implicates that the rights and freedom of government, enterprises, and social forces are equal, as they intend to contribute to the improvement of food safety. Such rights and freedom are not directly reflected by the legislation power defined by law. On the contrary, due to heterogeneous but complementary capabilities that are possessed by these different parties, government, enterprises, and social forces could all contribute differently but effectively to 
food safety for the whole society. Overall, the connotation of food safety risk co-governance is visually depicted in Figure 1.

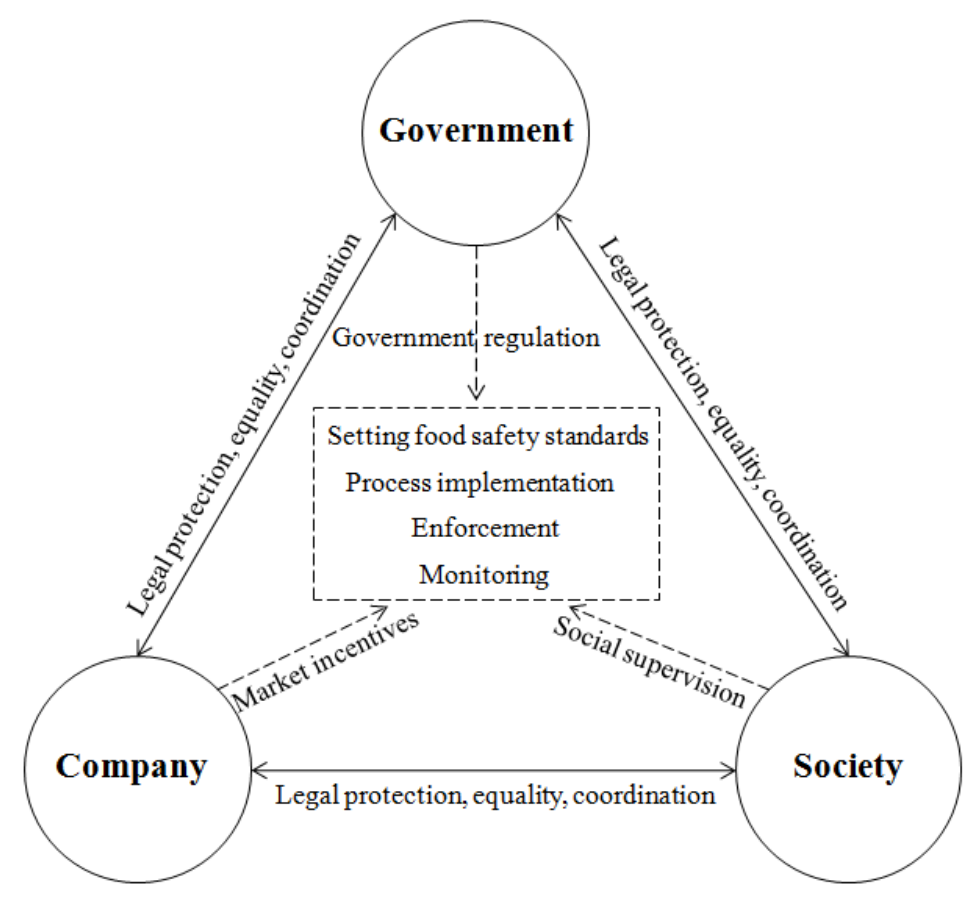

Figure 1. Connotation of food safety risk co-governance.

\section{Operational Logic of Food Safety Risk Co-Governance}

Since the 1990s, public governance theory has developed rapidly and it has become a popular topic in social science research. When compared with traditional social management theories, public governance theory overcomes the simplistic dichotomy between government and market. It recognizes the objective existence of "government failure" and "market failure", and even their coexistence in some areas, and it suggests that the third sector, also known as the "third hand", has to be introduced into the governance of public affairs. Moreover, the theory argues that the government, the market, and the third sector should be in equal positions and form a coordinated and effective network in order to more effectively distribute social benefits and ensure the maximization of social welfare. Based on public governance theory $[39,40]$, food safety is characterized by inseparable utility, nonrivalrous consumption, and nonexcludable benefits; therefore, food safety possesses the characteristics of public goods. The occurrence of food quality and safety incidents can cause public health damage, have a significant impact on the healthy development of the food industry, and even pose a huge threat to social and political stability; therefore, food safety risks are a public crisis [41,42]. Hence, it is the responsibility of the government to prevent food safety risks and ensure food safety. However, food is also an ordinary good. The demand for food production and the supply of the entire society should be met through market mechanisms. Nevertheless, food possesses search, experience, and credence attributes. As one of the attributes, credence (e.g., pesticide residues in vegetables or oil used in hot pots), cannot be ascertained by consumers until sometime after purchase or can never be ascertained. This, however, is often clear to producers [43]. As market failure is caused by food safety information asymmetry between producers and consumers [7], government intervention is therefore required. Traditional theories and practices of food safety risk governance are mainly based on the principle of "improving government regulation".In fact, when considering the changes in the food safety risk governance system, developed countries generally initially adopted a government-led approach. However, in the context of the increasing specialization in food production and the gradual internationalization of food trade, the government has its own limitations. In other words, the 
government fails in food safety risk governance [44]. Due to its complexity, diversity, and technical and social nature, food safety risk governance cannot rely solely on the government. Therefore, the focus should not only be on government governance and corporate self-governance, but also on the engagement of social actors, such as social organizations and the general public, thereby achieving effective co-governance by the entire society $[45,46]$.

As a new form of governance, the emergence of co-governance has completely changed the understanding of ex-post food safety risk governance and has compensated for the shortcomings of the traditional government regulation approach [47]. Based on the research results of May and Burby [48], Elodie and Julie [37] developed a framework for analyzing co-governance in enforcing food safety, as shown in Figure 2.

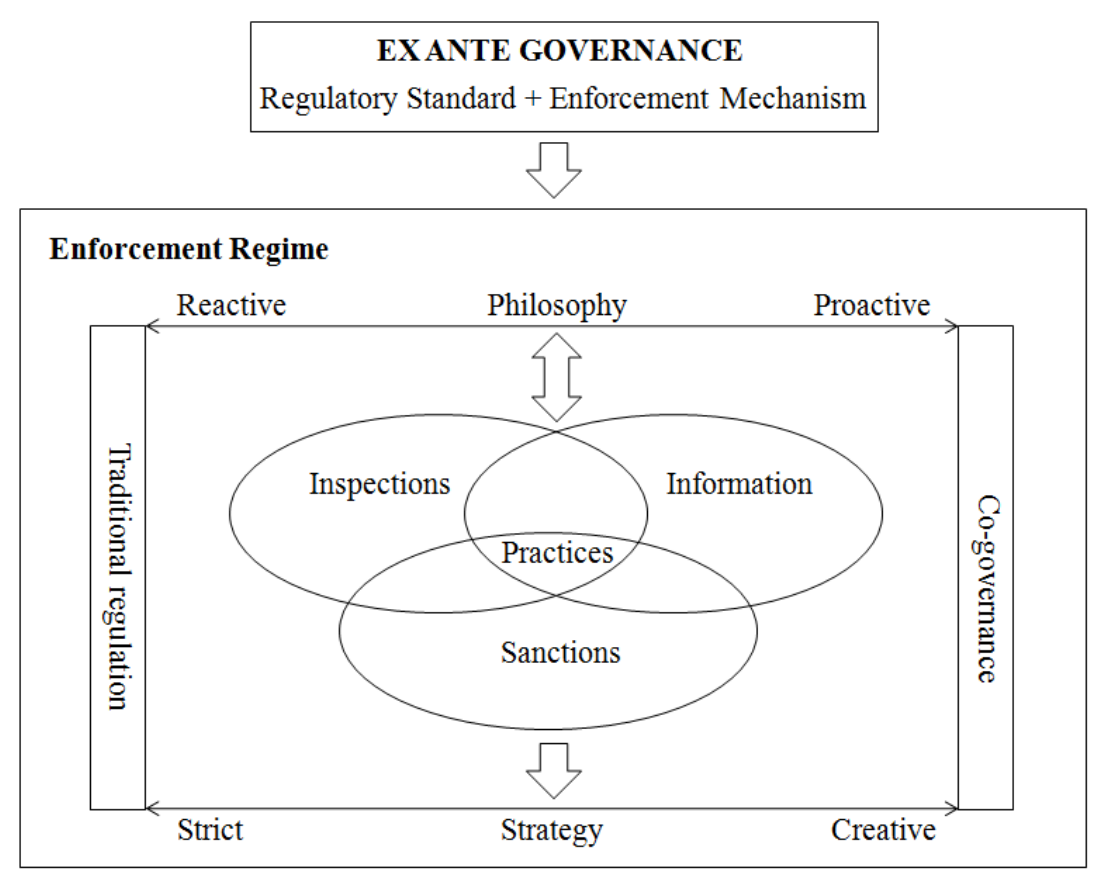

Figure 2. A framework for analyzing co-governance in enforcing food safety. Source: Elodie and Julie (2012).

From the perspective of both philosophy andstrategy, co-governance is more proactive and creative in managing food safety risks. For example, traditional regulation by the government alone imposes severe punishment on corporate offenders identified by random inspections. In contrast, co-governance brings together various actors to prevent corporate violations through a series of measures, such as education and training, and it encourages corporate compliance with the law through targeted inspections and market incentives. Therefore, co-governance enables more actors to participate in food safety risk governance, thereby improving governance flexibility, extending policy applicability, and reducing public costs $[29,31]$. The practices in developed countries have proved that co-governance brings about significant changes in food safety risk governance. Based on the literature, these changes can be summarized into three categories.

\subsection{A New Combination and Qualitative Improvement of Regulatory Capacity}

When compared with traditional governance, co-governance engages nongovernment actors, such as social organizations, companies, the media, and the public, in food safety risk governance through effective mechanisms. The result is that a much larger number of actors are able to play a role in governance [21]. Social actors play an important role in providing higher quality and safer food in a way that complements government governance [21]. Food industry organizations and manufacturers are generally more aware of food quality, while governments can create reputation-based incentives 
to monitor food quality. This indicates strong complementarity between government governance and corporate and social governance [49]. Co-governance allows all actors to give full play to their competence [50] and it is thus more effective than traditional governance [11,36]. For example, in the framework of the EU food hygiene regulations, governments, companies, social organizations, and citizens have actively participated in the regulation of food safety and played an important role in ensuring food safety [51].

\subsection{New Improvements in Qualityand the Practicality of Legal Standards}

Co-governance improves the quality and practicality of legal standards in food safety regulation. On the one hand, expertise in food quality and safety is the basis for the development of appropriate laws [33]. The engagement of nongovernment actors, such as companies and industry organizations, can help in the development of more wellconsidered food safety standards and regulations, owing to their unique advantages in this regard [19]. On the other hand, the government can directly upgrade the nongovernmental standards that were developed by companies or industry organizations to national legal standards [31]. Since these standards are based on expertise in the food industry, they can be applied relatively perfectly to the food industry and are considered to be the most adequate and effective [52,53]. Moreover, food companies feel a sense of belonging and ownership [54] and are more likely to understand and comply with new legal standards developed with their participation [55]. In the EU, legal food safety standards have combined government standards with industry and corporate standards $[16,56,57]$.

\subsection{New Changes in Governance Efficiency and Cost}

Co-governance can reduce the cost and improve the efficiency of food safety regulation. The participation of multiple actors helps to achieve decisions that are in line with the actual corporate or industry situation, thereby improving the practicality of the decisions that are made and reducing the burden on all actors [58]. Moreover, co-governance can distinguish between high-risk and low-risk companies, so the government can carry out targeted inspections. This will lead to greater pressure on high-risk companies and a reduced burden on law-abiding companies [59]. In the United Kingdom, farms participating in farm insurance are inspected at a rate of $2 \%$, while nonparticipating farms are inspected at a rate of $25 \%$. This has led to a cost reduction of $£ 571,000$ per year for participating farms and $£ 2$ million for the local government agencies [60].

Co-governance mode for food safety is beneficial for the collaboration among government, enterprises, and social forces, with their heterogeneous but complementary capabilities being fully utilized. As to the capability of distinguishing between high- versus and low-risk companies, China's can also serve as a good example. With the big data accumulated by China's Customs regarding the rejected food by other countries, clear identification of high-risk companies with highly rejected items as their core products could be made. Such big data is shared among the three major actors of the co-governance system, in order to allow government's monitoring, enterprises' self-reflection, and social forces' warning functions. Even the consumers could adjust their consumption behaviors based on such data sources [61]. In sum, as compared to the government dominating model of food safety governance with single source of information, the risk identifying capability is largely improved (in co-governance mode) by transparent information flows among government, enterprises, social forces, and even consumers.

Therefore, when compared with traditional government regulation, co-governance is more flexible and efficient in regulating food safety. Under the operational logic of co-governance, food safety risk governance has transformed from a traditional punishment-oriented approach to a modern prevention-oriented approach [37]. 


\section{Role of Government in Food Safety Risk Co-Governance}

The traditional theoretical research on food safety risk governance is mainly based on the principle of "improving government regulation", with an emphasis on severe punishment. In the 1990s, under public pressure from frequent flagrant food safety incidents, developed countries strengthened their food safety risk governance by ex-ante legislation and ex post direct intervention based on the principle of severe punishments [11]. However, due to the complexity, diversity, technicality, and sociality of food safety risk governance, it was later realized that there were substantial problems in relying solely on administrative departments to enforce food safety. Colin et al. argue that the fragmented organization of regulatory agencies leads to significant dissipation and the weakening of the regulatory capacity and even administrative corruption, such as rent seeking and rent setting [62].

Despite all of these problems with traditional regulation, the government plays an irreplaceable role in food safety risk co-governance [63]. In fact, it is of the utmost importance for the government to identify its role and scope in co-governance. David et al. propose that the government needs to steer rather than row and to empower rather than serve [64]. In contrast, Janet and Robert argue that the government needs to serve rather than steer in order to meet the individual needs of citizens as much as possible without making decisions for them [65]. The Better Regulation Task Force suggests that, for any given food safety problem, the level of government intervention may range from doing nothing-leaving the market to find the requisite solution-to direct regulation [66]. Garcia further divides government governance into six stages in terms of intervention level: no government intervention, corporate self-governance, co-governance, information and education, market incentives, and direct government command and control (Table 1) [21]. At the third stage, co-governance, the government has a specific function and role.

Table 1. Government intervention in food safety risk governance.

\begin{tabular}{lll}
\hline Stage & Intervention & Description \\
\hline 1 & No government intervention & No action \\
\hline 2 & Corporate self-governance & $\begin{array}{l}\text { Voluntary code of conduct } \\
\text { Farm management system } \\
\text { Corporate quality management system }\end{array}$ \\
\hline 3 & Co-governance & $\begin{array}{l}\text { Regulation by law } \\
\text { Governance by government policies and management measures }\end{array}$ \\
\hline 5 & Information and education & $\begin{array}{l}\text { Communicating information on food safety regulation to the public } \\
\text { Providing information and guidance to consumers } \\
\text { Publishing the identities of violating companies }\end{array}$ \\
\hline 6 & Market incentives & $\begin{array}{l}\text { Rewarding companies for safe production } \\
\text { Creating market incentives for investment in food safety }\end{array}$ \\
\hline & & $\begin{array}{l}\text { Direct regulation } \\
\text { Law enforcement and inspectionSanctions and punishment for } \\
\text { violating companies }\end{array}$ \\
\hline
\end{tabular}

The basic functions of the government in food safety risk co-governance are further described as follows.

\subsection{Creating an Institutional Environment That Guarantees Market and Social Order}

In the framework of co-governance, the most important responsibility of the government as a leader is to create an institutional environment that guarantees market and social order [67]. It is the responsibility of the government to ensure that companies produce food according to legal standards [37]. Moreover, the government has the responsibility to establish an effective mechanism for punishing violating companies under the legal framework, which is conducive to building consumer confidence in food safety risk governance [61]. However, government regulation and punishment 
should be set at a level that encourages companies to voluntarily implement quality assurance systems, such as Hazard Analysis and Critical Control Point (HACCP), without undermining their enthusiasm and decision-making flexibility in autonomous production. This is a major challenge for governments [31].

\subsection{Establishing a Compact and Flexible Regulatory Structure}

The effectiveness of food safety risk governance depends on the regulatory structure. A decentralized, inflexible structure can severely limit the ability of actors to cope with changing food safety risks $[68,69]$. Therefore, the government needs to construct a compact and flexible co-governance structure by employing different combinations of policy instruments that are based on the actual situation $[70,71]$. The lack of trust between actors in the food supply chain can seriously impede cooperation $[21,38]$. Therefore, information exchange and legislation should form an essential component of the regulatory structure in order to address the distrust in the regulatory structure through information disclosure and exchange [72].

\subsection{Building a Collaborative Partnership with Companies and Social Actors}

As a key actor in public governance, the government should exert its strong influence on bringing together companies and social actors in food safety risk governance by continuously promoting cooperation with companies, social organizations, and individuals, etc. [36]. The government should build an equal, coordinated, orderly, friendly, and collaborative partnership with companies, consumers, social organizations, and other actors with an open and inclusive attitude in the system of food safety risk co-governance. On the other hand, efforts should also be made to reduce buck-passing and disinterest among government agencies to improve the regulatory capacity [73]. Moreover, government information should be disclosed in an open and transparent manner to increase the trust of other actors in the government in order to promote cooperation with companies and social actors and to create a harmonious and orderly co-governance environment [74]. In addition, providing timely information, education, and training for food companies can improve the relationship between the government and companies [32,75].

\section{Role of Companies in Food SAFETY risk Co-Governance}

The behaviors of food companies, especially producers, directly or indirectly determine food quality and safety. Co-governance requires food companies to assume more responsibility for food safety [37]. However, the ultimate goal of companies is to obtain economic benefits. Food producers and traders decide whether to comply with food safety regulations based on the costs and benefits. The responses can range from full compliance to noncompliance [76]. Food companies also assess the costs and benefits of their internal (resource) and external (reputation and punishment) incentives and then determine the appropriate safeguards to achieve a certain food safety level based on budget limits, marketing strategies, and market structure [77]. Therefore, it is necessary to use market mechanisms to induce companies to fulfill their responsibilities as actors in food safety risk co-governance.

\subsection{Enhancing Corporate Self-Governance}

For companies, high food quality not only means no punishment but also a good reputation and consequent benefits. Enhancing corporate self-governance is an important part of ensuring food quality [38]. Corporate self-governance involves risk analysis and control. In this regard, HACCP is one of the most widely recognized approaches to preventing food safety risks and it has been implemented in many food companies within in the EU and the US [78]. While food quality and sales incentives can encourage companies to implement HACCP, its use is limited by company size [79]. Due to the lack of funds and technology, mediumand small companies, which account for the vast majority of food companies, find it difficult to implement HACCP and similar quality control systems and the need to implement self-regulation based on their own specific circumstances [32,80]. 


\subsection{Ensuring Food Quality through Contractual Mechanisms}

As food companies in developed countries often achieve quality and safety in food production and transactions through vertical contract incentives, the midstream and downstream manufacturers play a particularly important role in the food supply chain. To better control product quality, contract incentives will become increasingly common among farmers, processors, transporters, and retailers in the food supply chain. When the characteristics of the product being sold are easily identifiable, contract terms will focus on financial incentives; otherwise, the focus will be on defining specific inputs and behavioral requirements [81]. Downstream companies can use high-precision inspection systems to ensure the quality and safety of raw materials and half-done products from upstream companies and obtain compensation from upstream companies through contractual mechanisms in the case of food safety and quality problems. In this way, upstream companies are motivated to take measures to ensure the safety and quality of the food produced [82]. Therefore, participants in the food supply chain can control the quality of the final product for consumers through contract terms [83].

\subsection{Communicating Safety Information to Consumers}

Food companies can communicate safety information to consumers using instruments, such as certification, labeling and traceability systems, to solve food safety information asymmetry. In terms of certification and labeling, certification by local private organizations or at the farm level, as well as quality and safety standards that are established by retailers, has been used in addition to the certification standards set by international organizations and governments in developed countries [84]. An example, EUREP GAP (Good Agricultural Practice) is a standard developed by the Euro-Retailer Produce Working Group (EUREP) in compliance with the Anti-Trust Act to provide integrated farm assurance, integrated aquaculture assurance, and technical specifications for tea, flowers, and coffee, etc. [85]. These technical specifications are reflected in many ways, such as equipment standards, production processes, packaging processes, and quality management, and at times are even more stringent than the legal norms [86]. Traceability systems, on the one hand, allow for the differentiation of food with a safety credence attribute to ensure food safety for consumers, and, on the other hand, enable companies to reduce the costs in the production and marketing of risky food to obtain a net income [87].

\section{Role of Social Actors in Food Safety Risk Co-Governance}

Social actors are an important part of food safety risk co-governance. They are a powerful supplement to government governance and corporate self-governance and determine the success or failure of public policies [88-90]. Social actors are defined as basic units that can participate in and act on social development. As the "third sector", which is relatively independent of the government and market, social actors are mainly composed of citizens and various social organizations [91,92]. Social organizations mainly include associations, clubs, health care organizations, educational institutions, social service agencies, advocacy groups, foundations, and self-help groups with membership requirements [93]. As the state-society and public-private link, social organizations tend to establish equal and mutually beneficial cooperation in accordance with the interests of the majority of the public. Such efforts can reduce the uncertainty of regulatory policies and effectively compensate for government and market failures [94]. On the one hand, social organizations can supervise government activities and force the government to correct misconduct, thus compensating for government failure [95]. On the other hand, in the case of contract failure in the market, nonprofit social organizations can effectively restrict the opportunism of producers in order to remedy market failure, thereby meeting public demand for social public goods [96]. Social organizations in the US and EU often participate in food safety regulation through organized demonstrations, protests, publicity, and boycotts [97]. 
Individuals are the best judges of their own actions [98]. Therefore, every citizen is the best regulator of food safety. Citizens can participate in food safety regulation anytime, anywhere, and in various ways, such as through the Internet, which is a convenient and easily accessible means [99]. However, it is difficult even for scientists in the field of food safety to fully understand food safety due to its vast content. Therefore, it is difficult for the public, which has relatively limited knowledge of food safety, to effectively participate in food safety risk governance. Nevertheless, improving the transparency and traceability of food safety systems can significantly enhance consumers' regulatory capability [100]. For example, because of concerns about the safety of genetically modified food, citizens have called for and required adequate information disclosure by the government and companies in order to protect their rights [101].

\section{Summary and Future Research}

In summary, the connotation and operational logic of food safety risk co-governance, as well as the role and scope of each actor, have been extensively described in the literature. This has important implications for further theoretical research and the practice of food safety risk co-governance. In particular, the relationship between the government and food companies has been transformed from the traditional unequal regulator-regulatee relationship to an equal collaborative interactive relationship with particular emphasis on corporate self-governance. However, experiences from other countries need to be adapted due to institutional differences. The current definition and practice of food safety risk co-governance in every country is based on its own circumstances. For example, in the vertical regulatory system that was implemented by the US federal government, national public goods are mainly supplied by the central government, with an emphasis on the self-regulation of food producers. In other countries, in contrast, local governments may take overall responsibility for food safety regulation based on the principle of reducing social risks. Therefore, to add dedicated knowledge to the literature, future studies are encouraged to conduct context-specific investigations that help explicate special institutional, economic, and societal characteristics that might make the practices of social co-governance different from that of other countries. To take China as an instance, its food safety situation has attracting attentions, since it is one that with the highest amount of population with huge needs in food consumption. Although China's food safety risk governance standards have been improved rapidly in recent years, it still faces problems and has room for improvement. Therefore, promoting empirical research on the social co-governance of food safety risks in China has positive and practical significance. Future studies may follow these suggested three directions. First, China's food safety governance is based on the responsibility system taken heavily by local governments, while non-government organizations have played relative insignificant roles. It might be important to investigate on how local government could motivate and leverage the capabilities of non-governance organizations to benefit on co-governance. Second, there is a large number of micro-enterprises (i.e., owning less than ten workers) in China's food industries. It would be a great challenge to encourage self-regulation for these micro-enterprises. Third, it is also important to research on the context-specific construction of a food safety co-governance system of China's own, additional to referencing western countries' practices.

Author Contributions: L.W. led the project, conceptualized and write for the original draft of the paper; Y.L. was a major co-writer for the first draft. X.C. sorted and logically analyzed the literature; F.-S.T. reviewed and validated the manuscript and was in charge of the revision and resubmission.

Funding: We acknowledge the partial supports from the Study of Multiple Simulation Experiment on Traceable Food Consumption Policy based on Consumer Preferences: The Case of Pork, a project of the National Natural Science Foundation of China (Project Approval No. 71273117), and the Study of identification and early warning of food safety risks of production and supply processes as a key project of the National Natural Science Foundations of China (project approval No. 71633002).

Conflicts of Interest: The authors declare no conflict of interest. 


\section{References}

1. De Krom, M.P.M.M. Understanding Consumer Rationalities: Consumer Involvement in European Food Safety Governance of Avian Influenza. Sociol. Rural. 2009, 49, 1-19. [CrossRef]

2. Morse, T.D.; Masuku, H.; Rippon, S.; Kubwalo, H. Achieving an Integrated Approach to Food Safety and Hygiene-Meeting the Sustainable Development Goals in Sub-Saharan Africa. Sustainability 2018, 10, 2394. [CrossRef]

3. Sarig, Y. Traceability of Food Products. Agric. Eng. Int. CIGR J. Sci. Res. Dev. 2003, 4, 2-17.

4. Torretta, V.; Katsoyiannis, I.A.; Viotti, P.; Rada, E.C. Critical Review of the Effects of Glyphosate Exposure to the Environment and Humans through the Food Supply Chain. Sustainability 2018, 10, 950. [CrossRef]

5. Zhang, D.; Ma, Q.; Morse, S. Motives for Corporate Social Responsibility in Chinese Food Companies. Sustainability 2018, 10, 117. [CrossRef]

6. Yimin, W.; Shaohui, O.Y.; Weijun, L. Progress in food safety management and technology research. J. Agric. Sci. Technol. China 2005, 5, 55-57.

7. Antle, J.M. Effcient Food Safety Regulation in the Food Manufacturing Sector. Am. J. Agric. Econ. 1996, 78, 1242-1247. [CrossRef]

8. Cantley, M. How Should Public Policy Respond to the Challenges of Modern Biotechnology. Curr. Opin. Biotechnol. 2004, 15, 258-263. [CrossRef] [PubMed]

9. Halkier, B.; Holm, L. Shifting Responsibilities for Food Safety in Europe: An Introduction. Appetite 2006, 47, 127-133. [CrossRef] [PubMed]

10. Caduff, L.; Bernauer, T. Managing Risk and Regulation in European Food Safety Governance. Rev. Policy Res. 2006, 23, 153-168. [CrossRef]

11. Henson, S.; Caswell, J. Food Safety Regulation: An Overview of Contemporaryissues. Food Policy 1999, 24, 589-603. [CrossRef]

12. Henson, S.; Hooker, N. Private Sector Management of Food Safety: Public regulation and the Role of Private Controls. Int. Food Agribus. Manag. Rev. 2001, 4, 7-17. [CrossRef]

13. Codron, J.M.; Fares, M.; Rouvière, E. From Public to Private Safety Regulation? The Case of Negotiated Agreements in the French Fresh Produce Import Industry. Int. J. Agric. Resour. Gov. Ecol. 2007, 6, $415-427$. [CrossRef]

14. Vos, E. EU Food Safety Regulation in the Aftermath of the BES Crisis. J. Consum. Policy 2000, 23, $227-255$. [CrossRef]

15. Flynn, A.; Carson, L.; Lee, R.; Marsden, T.; Thankappan, S. The Food Standards Agency: Making A Difference; Centre For Business Relationships Accountability Sustainability and Society (Brass); Cardiff University: Cardiff, UK, 2004.

16. Ansell, C.; Vogel, D. What's the Beef: The Contested Governance of European Food Safety; MIT Press: Cambridge, MA, USA, 2006.

17. Osborne, D.; Gaebler, T. Reinventing Government: How the Entrepreneurial Spirit is Transforming the Public Sector. Revista De Administração De Empresas 1993, 33, 59-60.

18. Scott, C. Analysing Regulatory Space: Fragmented Resources and Institutional Design. Public Law Summer 2001, 1, 229-352.

19. Ansell, C.; Vogel, D. What's the Beef: The Contested Governance of European Food Safety; MIT Press: Cambridge, MA, USA, 2006; pp. 67-68.

20. Henson, S.; Humphrey, J. The Impacts of Private Food Safety Standards on the Food Chain and on Public Standard-Setting Processes. In Proceedings of the International Conference on Intelligent Computation Technology \& Automation, Ulsan, Korea, 16-19 September 2009; Volume 3, pp. 980-983.

21. Marian, G.M.; Fearneb, A.; Caswellc, J.A.; Henson, S. Co-Regulation as A Possible Model for Food Safety Governance: Opportunities for Public-Private Partnerships. Food Policy 2007, 32, 299-314.

22. Claus, O.; John, K. Contradictions of the Welfare State; Routledge: Milton, MA, USA, 2018.

23. James, P.G. Managing Nonprofit Organizations in the 21st Century; Greenwood Press: Santa Barbara, CA, USA, 1992.

24. Commission on Global Governance. Our Global Neighbourhood: The Report of the Commission on Global Governance; Oxford University Press: London, UK, 1995.

25. Mueller, R.K. Changes in the Wind in Corporate Governance. J. Bus. Strategy 1981, 1, 8-14. [CrossRef] 
26. Bressers, T.A. The Choice of Policy Instruments in Policy Networks. In Public Policy Instruments Evaluating Tools of Public Administration; Edward Elgar: Cheltenham, UK, 1998; pp. 85-105.

27. Stoker, G. Governance as Theory: Five Propositions. Int. Soc. Sci. J. 1998, 155, 17-28. [CrossRef]

28. Zhang, M.; Wen, J.; Liu, Z. Industry Self-discipline, Social Supervision and Vertical Collaboration: Research on Food Safety Behavior Based on the Perspective of Social Co-governance. Ind. Econ. Res. 2017, 86, 89-99. (In Chinese)

29. Ayres, I.; Braithwaite, J. Responsive Regulation: Transcending the Deregulation Debate; Oxford University Press: New York, NY, USA, 1992.

30. Gunningham, N.; Rees, J. Industry Self Regulation: An Institutional Perspective. Law Policy 1997, 19, $363-414$. [CrossRef]

31. Coglianese, C.; Lazer, D. Management-Based Regulation: Prescribing Private Management to Achieve Public Goals. Law Soc. Rev. 2003, 37, 691-730. [CrossRef]

32. Fairman, R.; Yapp, C. Enforced Self-Regulation, Prescription, and Conceptions of Compliance within Small Businesses: The Impact of Enforcement. Law Policy 2005, 27, 491-519. [CrossRef]

33. Sinclair, D. Self-Regulation Versus Command and Control? Beyond False Dichotomies. Law Policy 1997, 19, 527-559. [CrossRef]

34. Bartle, I.; Vass, P. Self-Regulation and the Regulatory State: A Survey of Policy and Practices; University of Bath: Bath, UK, 2005.

35. Organisation for Economic Cooperation and Development (OECD). Regulatory Policies in OECD Countries, from Interventionism to Regulatory Governance; Report OECD; OECD: Paris, France, 2002.

36. Eijlander, P. Possibilities and Constraints in the Use of Self-Regulation and Coregulation in Legislative Policy: Experience in the Netherlands-Lessons to be Learned for the EU. Electron. J. Comp. Law 2005, 9, 1-8.

37. Elodie, R.; Julie, C. From Punishment to Prevention: A French Case Study of the Introduction of Co-Regulation in Enforcing Food Safety. Food Policy 2012, 37, 246-254.

38. Fearne, A.; Martinez, M.G. Opportunities for the Coregulation of Food Safety: Insights from the United Kingdom. Choices Mag. Food Farm Resour. Issues 2005, 20, 109-116.

39. Edwards, M. Participatory Governance into the Future: Roles of the Government and Community Sectors. Aust. J. Public Adm. 2001, 60, 78-88. [CrossRef]

40. Skelcher, C.; Mathur, N. Governance Arrangements and Public Sectorperformance: Reviewing and Reformulating the Research Agenda. SSRN Electron. J. 2004, 23-24.

41. Christian, H.; Klaus, J.; Axel, V. Better Regulation by New Governance Hybrids? Governance Styles and the Reform of European Chemicals Policy. J. Clean. Prod. 2007, 15, 1859-1874.

42. Krueathep, W. Collaborative Network Activities of Thai Subnational Governments: Current Practices and Future Challenges. Int. Public Manag. Rev. 2008, 9, 251-276.

43. Tirole, J. The Theory of Industrial Organization; The MIT Press: Cambridge, MA, USA, 1988.

44. Weisbrod, B.A.; Andreano, R.L.; Baldwin, R.E.; Epstein, E.H.; Kelley, A.C.; Helminiak, T.W. Disease and Economic Development: The Impact of Parasitic Diseases in St. Luci. Int. J. Soc. Econ. 1974, 1, 111-117. [CrossRef]

45. Cohen, J.L.; Arato, A. Civil Society and Political Theory; MIT Press: Cambridge, MA, USA, 1992.

46. Mutshewa, A. The Use of Information by Environmental Planners: A Qualitative Study Using Grounded Theory Methodology. Inf. Process. Manag. 2010, 46, 212-232. [CrossRef]

47. Black, J. Decentring Regulation: Understanding the Role of Regulation and Self Regulation in A 'Post-Regulatory' World. Curr. Leg. Probl. 2001, 54, 103-147. [CrossRef]

48. May, P.; Burby, R. Making Sense out of Regulatory Enforcement. Law Policy 1998, 20, 157-182. [CrossRef]

49. Nuñez, J. A Model of Selfregulation. Econ. Lett. 2001, 74, 91-97. [CrossRef]

50. Commission of the European Communities. European Governance. A White Paper, Com(2001)428[EB/OL]. Available online: http:/ / europa.eu/rapid/press-release_DOC-01-10_en.htm (accessed on 25 July 2001).

51. Commission of the European Communities. Report from the Commission to the Council and the European Parliament on the Experience Gained from the Application of the Hygiene Regulations (Ec) No 852/2004, (Ec) No 853/2004 and (Ec) No 854/2004 of the European Parliament and of the Council of 29 April 2004, Sec(2009) 1079; EUR-Lex: Brussels, Belgium, 2009.

52. Kerwer, D. Rules that Many Use: Standards and Global Regulation. Governance 2005, 18, 611-632. [CrossRef] 
53. Demortain, D. Standardising through Concepts, the Power of Scientific Experts in International Standard-Setting. Sci. Public Policy 2008, 35, 391-402. [CrossRef]

54. Ansell, C.; Vogel, D. What's the Beef: The Contested Governance of European Food Safety; MIT Press: Cambridge, MA, USA, 2006.

55. Baldwin, R.; Cave, M. Understanding Regulation: Theory, Strategy, and Practice; Oxford University Press: Oxford, UK, 1999.

56. Lee, R.; Marsden, T.; Flynn, A. The New Regulation and Governance of Food: Beyond the Food Crisis; Routledge: New York, NY, USA; London, UK, 2010.

57. Brunsson, N.; Jacobsson, B. A World of Standards; Oxford University Press: Oxford, UK, 2000.

58. Garcia, M.M.; Verbruggen, P.; Fearne, A. Risk-Based Approaches to Food Safety Regulation: What Role for Co-Regulation. J. Risk Res. 2013, 16, 1101-1121. [CrossRef]

59. Hampton, P. Reducing Administrative Burdens: Effective Inspection and Enforcement; HM Treasury: London, UK, 2005.

60. Food Standards Agency. Safe Food and Healthy Eating for All, Annual Report 2007/08; The Food Standards Agency: London, UK, 2008.

61. Wu, L.; Chen, X.; Yi, S. China Development Report on Food Safety; Peking University Press: Beijing, China, 2017; pp. 171-192. (In Chinese)

62. McInnes, C.; Kamradt-Scott, A.; Lee, K.; Reubi, D.; Roemer-Mahler, A.; Rushton, S.; Williams, O.D.; Woodling, M. Framing Global Health: The Governance Challenge. Glob. Public Health 2012, 7, 83-94. [CrossRef] [PubMed]

63. Hutter, B.M. The Role of Non State Actors in Regulation; The Centre for Analysis of Risk and Regulation (CARR), London School Of Economics And Political Science: London, UK, 2006.

64. David, O.; Ted, G. Reinventing Government. Public Prod. Manag. Rev. 1993, 16, 349-356.

65. Janet, V.D.; Robert, B.D. The New Public Service: Serving, Not Steering; M.E. Sharpe: Armonk, NY, USA, 2002.

66. Better Regulation Task Force. Imaginative Thinking for Better Regulation; Cabinet Office: London, UK, 2003.

67. Hadjigeorgiou, A.; Soteriades, E.S.; Gikas, A. Establishment of A National Food Safety Authority for Cyprus: A Comparative Proposal Based on the European Paradigm. Food Control 2013, 30, 727-736. [CrossRef]

68. Dyckman, L.J. The Current State of Play: Federal and State Expenditures on Food Safety; Resource for the Future: Washington, DC, USA, 2005.

69. Merrill, R.A. The Centennial of US Food Safety Law: A Legal and Administrative History; Resource for the Future: Washington, DC, USA, 2005.

70. Dorbeck-Jung, B.R.; Oude Vrielink, M.J.; Gosselt, J.F.; Van Hoof, J.J.; De Jong, M.D. Contested Hybridization of Regulation: Failure of the Dutch Regulatory System to Protect Minors from Harmful Media. Regul. Gov. 2010, 4, 154-174. [CrossRef]

71. Saurwein, F. Regulatory Choice for Alternative Modes of Regulation: How Context Matters. Law Policy 2011, 33, 334-366. [CrossRef]

72. Jia, C.; Jukes, D. The National Food Safety Control System of China-Systematic Review. Food Control 2013, 32, 236-245. [CrossRef]

73. Hall, D. Food with A Visible Face: Traceability and the Public Promotion of Private Governance in the Japanese Food System. Geoforum 2010, 41, 826-835. [CrossRef]

74. Mol, A.P.J. Governing China's Food Quality through Transparency: A Review. Food Control 2014, 43, 49-56. [CrossRef]

75. Fearne, A.; Garcia, M.M.; Bourlakis, M. Review of the Economics of Food Safety and Food Standards, Document Prepared for the Food Safety Agency; Imperial College London: London, UK, 2004.

76. Henson, S.; Heasman, M. Food Safety Regulation and the Firm: Understanding the Compliance Process. Food Policy 1998, 23, 9-23. [CrossRef]

77. Loader, R.; Hobbs, J. Strategic Responses to Food Safety Legislation. Food Policy 1999, 24, 685-706. [CrossRef]

78. Jones, S.L.; Parry, S.M.; O’BRIEN, S.J.; Palmer, S.R. Are Staff Management Practices and Inspection Risk Ratings Associated with Foodborne Disease Outbreaks in the Catering Industry in England and Wales. J. Food Prot. 2008, 71, 550-557. [CrossRef] [PubMed]

79. Dimitrios, P.K.; Evangelos, L.P.; Panagiotis, D.K. Measuring the Effectiveness of the HACCP Food Safety Management System. Food Control 2013, 33, 505-513. 
80. Fielding, L.M.; Ellis, L.; Beveridge, C.; Peters, A.C. An Evaluation of HACCP Implementation Status in UK SME's in Food Manufacturing. Int. J. Environ. Health Res. 2005, 15, 117-126. [CrossRef] [PubMed]

81. Wu, L.; Zhu, D. Food Safety in China: A Comprehensive Review; CRC Press: Boca Raton, FL, USA, 2014.

82. Starbird, S.A.; Amanor-Boadu, V. Contract Selectivity, Food Safety, and Traceability. J. Agric. Food Ind. Organ. 2007, 5, 1-23. [CrossRef]

83. Ajay, D.; Handfield, R.; Bozarth, C. Profiles in Supply Chain Management: An Empirical Examination. In Proceedings of the 33rd Annual Meeting of the Decision Sciences Institute, San Diego, CA, USA, 23-26 November 2002.

84. Caswell, J.A.; Mojduszka, E.M. Using Information Labeling to Influence the Market for Quality in Food Products. Am. J. Agric. Econ. 1996, 78, 1248-1253. [CrossRef]

85. Roth, E.; Rosenthal, H. Fisheries and Aquaculture Industries Involvement to Control Product Health and Quality Safety to Satisfy Consumer-Driven Objectives on Retail Markets in Europe. Mar. Pollut. Bull. 2006, 53, 599-605. [CrossRef] [PubMed]

86. Grazia, C.; Hammoudi, A. Food Safety Management by Private Actors: Rationale and Impact on Supply Chain Stakeholders. Rivista Di Studi Sulla Sostenibilita' 2012, 2, 111-143.

87. Wu, L.; Wang, H.; Zhu, D. Analysis of Consumer Demand for Traceable Pork in China Based on a Real Choice Experiment. China Agric. Econ. Rev. 2015, 7, 303-321. [CrossRef]

88. Bardach, E. The Implementation Game: What Happens after a Bill Becomes a Law; The MIT: Cambridge, MA, USA, 1978.

89. Pressman, J.L.; Wildavsky, A. Implementation: How Great Expectations in Washington Are Dashed in Oakland, 3rd ed.; University of California Press: Los Angeles, CA, USA, 1984.

90. Lipsky, M. Street-Level Bureaucracy: Dilemmas of the Individual in Public Services; Russell Sage Foundation: New York, NY, USA, 2010.

91. Maynard-Moody, S.; Musheno, M. Cops, Teachers, Counsellors: Stories from the Frontlines of Public Services; University of Michigan Press: Ann Arbor, MI, USA, 2003.

92. Jeannot, G. Les FonctionnairesTravaillent-Ils De Plus En Plus? Un Double InventaireDesRecherches Sur L'Activité Des Agents Publics. Revue Française De Science Politique 2008, 58, 123-140. [CrossRef]

93. Lester, M.S.; Sokolowski, S.W. Global Civil Society: Dimensions of the Nonprofit Sector; Johns Hopkins Center for Civil Society Studies: Baltimore, MD, USA, 1999.

94. Putnam, R.D. Making Democracy Work: Civic Traditions in Modern Italy; Princeton University Press: Princeton, NJ, USA, 1993.

95. Bailey, A.P.; Garforth, C. An Industry Viewpoint on the Role of Farm Assurance in Delivering Food Safety to the Consumer: The Case of the Dairy Sector of England and Wales. Food Policy 2014, 45, 14-24. [CrossRef]

96. Green, J.M.; Draper, A.K.; Dowler, E.A. Short Cuts to Safety: Risk and Rules of Thumb in Accounts of Food Choice. Health Risk Soc. 2003, 5, 33-52. [CrossRef]

97. Davis, G.F.; Mcadam, D.; Scott, W.R. Social Movements and Organization Theory; Cambridge University Press: Cambridge, UK, 2005.

98. Richard, A.P. Economic Analysis of Law; Wolters Kluwer Law \& Business: Aspen, CO, USA, 2010.

99. Corradof, G.G. Food Safety Issues: From Enlightened Elitism towards Deliberative Democracy? An Overview of Efsa's Public Consultation Instrument. Food Policy 2012, 37, 427-438.

100. Meijboom, F.V.; Brom, F. From Trust to Trustworthiness: Why Information is not Enough in the Food Sector. J. Agric. Environ. Ethics 2006, 19, 427-442. [CrossRef]

101. Todt, O.; Muñoz, E.; González, M.; Ponce, G.; Estévez, B. Consumer Attitudes and the Governance of Food Safety. Public Underst. Sci. 2009, 18, 103-114. [CrossRef] [PubMed]

(C) 2018 by the authors. Licensee MDPI, Basel, Switzerland. This article is an open access article distributed under the terms and conditions of the Creative Commons Attribution (CC BY) license (http:/ / creativecommons.org/licenses/by/4.0/). 